\title{
DIVERSITY OF ANTARCTIC MARINE MICROALGAE: EFFECTS OF ENVIRONMENTAL CHANGES ON COMPOSITION AND ABUNDANCE
}

http://dx.doi.org/10.4322/apa.2014.007

Denise Rivera Tenenbaum ${ }^{1 *}$, Priscila Kienteca Lange ${ }^{1}$, José Juan Barrera Alba ${ }^{1}$, Márcio Murilo Barboza Tenório, Giselle Parno Guimarães ${ }^{1}$, Luciano Felicio Fernandes ${ }^{2}$, Mariana Calixto ${ }^{2}$, Virgínia Maria Tavano Garcia ${ }^{3}$

\author{
'Laboratório de Fitoplâncton Marinho, Departamento de Biologia Marinha, Instituto de Biologia, \\ Universidade Federal do Rio de Janeiro - UFRJ, Rio de Janeiro, RJ, Brasil \\ ${ }^{2}$ Departamento de Botânica, Setor de Ciências Biológicas, \\ Universidade Federal do Paraná - UFPR, Curitiba, PR, Brasil \\ ²aboratório de Fitoplâncton e Microorganismos Marinhos, Departamento de Oceanografia, \\ Universidade Federal do Rio Grande, Rio Grande, RS, Brasil \\ *e-mail: deniser@biologia.ufrj.br
}

\section{Introduction}

In the Antarctic Ocean, phytoplankton constitutes the major group of aquatic primary producers (Medlin \& Priddle, 1990), synthesizing organic compounds from inorganic carbon through the process of photosynthesis, being the base of the food web. The phytoplankton is grazed on by Zooplankton (mainly the krill in Antarctic waters), fish larvae and invertebrate grazers, which in turn are consumed by top predators of the pelagic food web. Phytoplankton plays a key role on the biogeochemical cycles and on the transfer of organic matter and energy, being responsible for roughly half of the carbon fixation on Earth (Falkowski et al., 2000). As a consequence, oceans play a key role on the global carbon cycle and climate regulation (Chisholm et al., 2010).

Changes on phytoplankton composition and abundance are controlled by environmental factors such as light, inorganic nutrients availability, grazing and physical mechanisms (i.e. upwelling, turbulence, etc). In high latitudes, light is a key limiting factor since the remarkable seasonal variation of solar radiation and ice coverage lead to strong seasonality, reflected on phytoplankton composition and abundance (Whitaker, 1982).

Microscopic algae have the physiological ability to colonize numerous habitats. In Antarctic ecosystems, they have developed the skill to live in sea-ice and, during the summer, as the ice melts and retreats, it seeds the upper ocean with the microbial community from the ice and also fertilizes the ocean with iron and other nutrients (Smetacek \& Nicol, 2005). The melting process leads to the formation of a low salinity, stable surface layer, which prevents deep mixing of phytoplankton cells away from optimum light concentrations and a bloom can develop (Smith \& Nelson 1985).

Since they have a strong relationship with the water masses, the study of phytoplankton species composition and abundance has been used as a tool for environmental monitoring in several ecosystems. In this context, since 2002 the research group FITOMAR (Institute of Biology, UFRJ) has been investigating the microphytoplankton community structure on the inshore region of Admiralty Bay.

Traditionally, as noted above, Antarctic microalgae studies have been focused on phytoplankton due to its important role on the pelagic ecosystem. But, many 
investigations have demonstrated that high primary production rates observed in several periods were actually due to microphytobenthos contribution, especially in shallow areas (Palmisano \& Sullivan, 1983; White et al., 1993). Furthermore, this community constitutes the main food source for benthic invertebrates in bays and inlets, e.g. the Krill (Knox, 1994).

\section{Admiralty Bay}

Admiralty Bay $\left(62^{\circ} 03^{\prime}-12^{\prime} \mathrm{S}, 58^{\circ} 18^{\prime}-38^{\prime} \mathrm{W}\right)$, located at King George Island, is a deep fjord-like embayment with $500 \mathrm{~m}$ maximum depth at its center (Rakusa-Suszczewski et al. 1993). The waters from the bay mix with the oceanic deep waters from Bellingshausen and Weddell Seas at its southern opening, which connects to the Bransfield Strait (Rakusa-Suszczewski 1980; Lipski 1987). Water temperatures in early and late Summer are $-0,4 \pm 0,2{ }^{\circ} \mathrm{C}$ and $1,5 \pm 0,3^{\circ} \mathrm{C}$, respectively, while salinity varies between 34,6 $\pm 0,1$ and 33,9 $\pm 0,5$, for those periods (Lange et al, 2007). In the context of water column production, Admiralty Bay at nearshore can be considered as Platt et al. (2003) defined as "high nutrient - low chlorophyll (HNLC): showing high inorganic dissolved nitrogen $(16.6-46.9 \mu \mathrm{M})$ and phosphate $(0.2-9.9 \mu \mathrm{M})$ concentrations, while chlorophyll levels are lower than $1.7 \mu^{-1} ~^{-1}$ (Lange et al, 2007).

\section{What did we do?}

In the context of the PROANTAR (Programa Antártico Brasileiro), our activities began during the OPERANTAR XX (2002/2003) aiming to study the effects of environmental impacts (natural and anthropogenic) on the phytoplanktonic community structure, through analysis of long-term temporal series. These activities were developed until 2010, through four surveys, including samplings in both early and late austral summer periods.

\section{Phytoplankton variability in Admiralty Bay}

Microphytoplankton is dominated by diatoms, both in abundance (90\%) and in richness (77\%). Pennate diatoms are the main group in early summer, while centric diatoms show higher abundance in late summer (Lange et al., 2007). During the first part of the season, nearshore phytoplankton is characterized by nanoplanktonic organisms $(<20 \mu \mathrm{m})$ and pennate diatoms, mainly benthic species associated to sea-ice environment (ie. Cocconeis spp., Navicula spp. and Synedropsis spp.). After the melting and retreating of ice, a community characterized by a high abundance of typically pelagic diatoms (Corethron pennatum and several species of Fragilariopsis and Thalassiosira), adapted to the planktonic life, flourishes (Lange et al., 2007).

\section{New motivations}

Over the past several decades, the marine ecosystem along the western continental shelf of the Antarctic Peninsula (WAP) has undergone rapid warming, leading to changes in planktonic community (Ducklow et al., 2007). As a result, populations of sea ice-dependent species of lower and higher trophic levels are being demographically displaced poleward and are being replaced by ice-avoiding species (e.g., krill and microplanktonic diatoms are being replaced by salps and cryptophytes) (Montes-Hugo et al., 2009).

In Admiralty Bay, picoplankton and nanoplankton are the dominant groups, with microplankton diatoms as the second group in abundance. Between the decades of 1990 and 2000, several studies showed a decline in diatoms contribution (Kopczynska, 2008), in relation to those observed in the continental shelf region.

\section{Present and Future Studies}

New approaches of phytoplankton monitoring in Admiralty Bay will be established by our group, including the analysis of size-fractioned pigments by spectrofluorometry, phytoplankton analysis by FlowCAM (inflow imaging system) and the analysis of density and biovolume of pico and nanoplankton by epifluorescence microscopy, and also with a higher sampling frequency effort. Additionally, the composition of microphytobenthos species will be carried out to study the effects of environmental changes over this community in the nearshore Antarctic ecosystem. 


\section{References}

CHISHOLM, S. W.; FALKOWSKI, P. G.; CULLEN J. J. Dis-Crediting Ocean Fertilization. Science, v. 294, p. 309-310, 2010.

DUCKLOW, H. W. et al. Marine pelagic ecosystems: the West Antarctic Peninsula Philos. Transactions of the Royal Society of London, Serie B, v. 362, p. 67-94, 2007.

FALKOWSKI, P. et al. The Global Carbon Cycle: A Test of Our Knowledge of Earth as a System. Science, v. 290, p. 291-296, 2000.

KNOX, G. A. The biology of the Southern Ocean. Cambridge: Cambridge University Press, 1994. p. 193-220.

KOPCZYNSKA, E. E. Phytoplankton variability in Admiralty Bay, King George Island, South Shetland Islands: six years of monitoring. Polish Polar Research, v. 29, n. 2, p. 117-139, 2008.

LANGE, P. K. et al. Microphytoplankton assemblages in shallow waters at Admiralty Bay (King George Island, Antarctica) during the summer 2002-2003. Polar Biology, v. 30, p. 1483-1492, 2007.

LIPSKI, M. Variations of physical conditions, nutrients and chlorophyll a contents in Admiralty Bay (King George Island, South Shetland Islands). Polish Polar Research, v. 8, p. 307-332, 1987.

MEDLIN, L. K.; PRIDDLE, J. Polar Marine Diatoms. Cambridge, UK: British Antarctic Survey, 1990. p. 214.

MONTES-HUGO, M. et al. Recent Changes in Phytoplankton Communities Associated with Rapid Regional Climate Change Along the Western Antarctic Peninsula. Science, v. 323, p. 1470-1473, 2009.

PALMISANO, A. C.; SULLIVAN, C. W. Sea ice microbial communities (SIMCO). I. Distribution, abundance and primary production of ice microalgae in McMurdo Sound, Antarctica in 1980. Polar Biology, v. 2, p. 171-177, 1983.

PLATT, T. et al. Phytoplankton biomass and residual nitrate in the pelagic ecosystem. Proceedings of the Royal Society A, v. 459, p. 1063-1073, 2003.

RAKUSA-SUSZCZEWSKI, S. Environmental conditions and the functioning of Admiralty Bay (South Shetland Islands) as part of the near shore Antarctic ecosystem. Polish Polar Research, v. 1, n. 1, p. 11-27, 1980.

RAKUSA-SUSZCZEWSKI, S.; MIETUS, M.; PIASECKI, J. Weather and climate. In: RAKUSA-SUSZCZEWSKI, S (Ed.). The Maritime Coastal Ecosystem of Admiralty Bay. Warsaw: Dept. Antarctic Biol, Polish Academy of Science, 1993. p. 19-25.

SMETACEK, V.; NICOL, S. Polar ocean ecosystems in a changing world. Nature, v. 437, p. 362-368, 2005. doi:10.1038/ NATURE04161

SMITH, W. O.; NELSON, D. M. Phytoplankton bloom produced by a receding ice edge in the Ross Sea: Spatial coherence with the density field. Science, v. 227, p. 163-166, 1985. doi:10.1126/SCIENCE.227.4683.163

WHITAKER, T. M. Signy Island, South Orkneys, the Antarctic. Proceedings of the Royal Society London B, v. 214, n. 1195, p. 169-189, 1982.

WHITE, D. C. et al. 1993. Nearshore benthic marine sediments. In: FRIEDMANN, E. I. Antarctic Microbiology. New York: Wiley \& Liss, Inc., 1993. p. 219-240. 